Sitama, et al/Jurnal Ekonomi Syariah Teori dan Terapan Vol. 6 No. 3 Maret 2019: 599-624; FAKTOR-

FAKTOR PENILAIAN KEPUTUSAN KONSUMEN DALAM PEMBELIAN KOSMETIK HALAL (STUDI KASUS MAHASISWI MUSLIMAH FAKULTAS EKONOMI DAN BINIS UNIVERSITAS AIRLANGGA)

\title{
FAKTOR-FAKTOR PENILAIAN KEPUTUSAN KONSUMEN DALAM PEMBELIAN KOSMETIK HALAL (STUDI KASUS MAHASISWI MUSLIMAH FAKULTAS EKONOMI DAN BINIS UNIVERSITAS AIRLANGGA)'
}

\author{
Mega Fitria Sitama \\ Departemen Ekonomi Syariah-Fakultas Ekonomi dan Bisnis-Universitas Airlangga \\ Email: sitamamega@gmail.com
}

Eko Fajar Cahyono

Departemen Ekonomi Syariah-Fakultas Ekonomi dan Bisnis-Universitas Airlangga Email: fajars2ie@gmail.com

\begin{abstract}
:
This study aims to determine the assessment of prices, income, benefits, priority scale, perceptions of wasteful feelings and consumer decisions in purchasing halal cosmetics case studies of Unair Surabaya FEB female students. This study uses a quantitative approach with analysis of hypothesis testing. Retrieval of primary data in this study was conducted using a questionnaire. The sample in this study amounted to 357 students from the Faculty of Economics and Business, Airlangga University, Surabaya. Based on the results of the study, the valuation of prices consisting of prices (benefits), prices (affordable), prices (competing) partially has a significant effect. Revenue partially has a significant effect. Halal judgments, which consist of halal necessity, halal logo (competitor), halal logo (Islamic rules), halal logo (important aspects) partially have a significant effect. Assessment of benefits that consist of benefits (face), benefits (appearance), benefits (not allergies), benefits (long-term), partially significant effect. Evaluation of priority scale consists of priority scale (food), priority scale (health), priority scale (education), priority scale (residence) partially significant effect. Perception assessment consisting of perceptions (unique and funny packaging), perceptions (replace new ones), perceptions (moderate trends), partially have a significant effect. Consumer decision making partially has a significant effect.

Keywords: Price valuation, Income, Benefits, Priority Scale, Perception of Wasteful Feelings, Consumer Decisions, Halal Cosmetics.
\end{abstract}

\section{PENDAHULUAN}

Di dalam kehidupan manusia, semua manusia memiliki banyak sekali keperluan, keinginan dan segala kebutuhan-kebutuhan yang seluruhnya harus terpenuhi. Manusia membutuhkan kebutuhan untuk makan, minum, pakaian, pendidikan, kehormatan, pelayanan dan masih banyak kebutuhan lain-lain nya. Secara umum, segala kebutuhan yang dibutuhkan manusia itu terbagi menjadi dua kelompok besar, yaitu (1) kebutuhan fisik, (2) kebutuhan badaniah, dan (3) kebutuhan psikis atau yang sering disebut kebutuhan kejiwaan (Rosyidi, 2005:49).

Pemenuhan kebutuhan hidup dengan menggunakan suatu barang, maupun jasa guna dalam pemenuhan kebutuhan sehari-hari itulah yang sering disebut dengan konsumsi. Konsumsi dilakukan setiap hari oleh siapapun tujuannya untuk memperoleh kepuasan setinggi-tingginya dan berguna dalam mencapai tingkat kemakmuran dengan terpenuhinya segala aspek kebutuhan, baik itu kebutuhan primer (sandang,

\footnotetext{
${ }^{1}$ Jurnal ini merupakan bagian dari skripsi Mega Fitria Sitama, NIM: 041411433005 , yang diuji pada tanggal 23 Januari 2019.
} 
Sitama, et al/Jurnal Ekonomi Syariah Teori dan Terapan Vol. 6 No. 3 Maret 2019: 599-624; FAKTORFAKTOR PENILAIAN KEPUTUSAN KONSUMEN DALAM PEMBELIAN KOSMETIK HALAL (STUDI KASUS MAHASISWI MUSLIMAH FAKULTAS EKONOMI DAN BINIS UNIVERSITAS AIRLANGGA)

pangan, papan) dan sekunder, barang mewah (tersier) maupun kebutuhan jasmani dan rohani (Todaro, 2002:213).

Penampilan termasuk dalam kebutuhan fisik atau kebutuhan badaniah, Penampilan adalah suatu hal yang penting untuk setiap individu. Setiap individu pasti menginginkan penampilan yang terbaik disetiap aktivitasnya. Penampilan juga dapat menambah kepercayaan diri seseorang dalam menjalakan setiap aktivitasnya baik itu aktivitas di dalam atau aktivitas diluar. penampilan tidak hanya dilihat dari apa yang dikenakan oleh seseorang tersebut melainkan juga kesehatan dan kecantikan tubuh secara keseluruhan. Setiap kaum laki laki-laki dan perempuan pasti menginginkan wajah bersih, kulit yang indah, dan tubuh yang sehat dan bugar.

Kesehatan tubuh menjadi asset yang berharga yang wajib di jaga. Memiliki permasalahan dalam penampilan dapat menjadi kendala untuk melakukan setiap kegiatan, tidak peka dengan penampilan dapat menyebabkan kurang percaya diri dan tidak nyaman dalam melakukan aktivitas. Maka dari itu sebagai umat manusia sudah menjadi kewajiban untuk merawat kecantikan dan kesehatan tubuh dengan perawatan kulit dan tubuh yang cocok, tepat dan tidak berlebihan. Allah swt berfirman pada surat Al'araf ayat 31-32 :

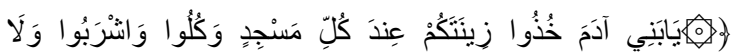

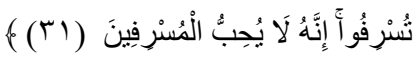

yā banī ādama khużụ zīnatakum 'inda kulli masjidiw wa kulụ wasyrabụ wa lā tusrifụ, innahụ lā yuhibbul-musrifin. Artinya: "Hai anak Adam, pakailah pakaianmu yang indah di setiap (memasuki) mesjid, makan dan minumlah, dan janganlah berlebih-lebihan. Sesungguhnya Allah tidak menyukai orang-orang yang berlebih-lebihan"

Kosmetik selalu digunakan para wanita dari pagi sampai malam hari menjelang tidur. Dari masa ke masa kecantikan bukan lagi hanya menjadi suatu keinginan melainkan sudah menjadi Kebutuhan wanita yang saat ini memberikan dampak pada semakin meningkatnya potensi pasar kosmetik. Tahun ke tahun produksi kosmetik semakin meningkat baik terhadap kosmetik produksi dalam negeri, maupun luar negeri. Berkembangnya perusahaan yang berusaha memenuhi kebutuhan para wanita akan kosmetik dengan berbagai macam inovasi produk beserta manfaatnya.

Ditambah berdasarkan data kementerian perindustrian (Kemenperin) Pertumbuhan industri yang memproduksi kosmetik berkembang pesat, Industri Kosmetik Nasional tumbuh 7,36\% pada kuartal I-2018, meningkat dibandingkan pada 2017 yang tumbuh 6,35\% seiring dengan itu jumlah perusahaan kosmetik di Indonesia juga bertambah sebanyak 153 perusahaan pada 2017 sehingga total saat ini mencapai lebih dari 760 perusahaan (www.duniaindustri.com). 
Sitama, et al/Jurnal Ekonomi Syariah Teori dan Terapan Vol. 6 No. 3 Maret 2019: 599-624; FAKTORFAKTOR PENILAIAN KEPUTUSAN KONSUMEN DALAM PEMBELIAN KOSMETIK HALAL (STUDI KASUS MAHASISWI MUSLIMAH FAKULTAS EKONOMI DAN BINIS UNIVERSITAS AIRLANGGA)

Menurut Dirjen Industri Kimia Tekstil dan Aneka (IKTA) Kemenperin Achmad Sigit Dwiwahjono mengatakan bahwa :

"Pada 2017, tercatat nilai Ekspor produk kosmetik nasional mencapai US\$516,99 juta, naik dibanding pada 2016 sebesar US\$470,30 juta, kemenperin terus memacu pengembangan industri kosmetik di dalam negeri agar berdaya saing global karena prospek bisnisnya cukup kemilau pada masa mendatang " (kemenperin, 2018).

Inovasi produk kosmetik yang semakin meningkat bertujuan mendapatkan kepercayaan dari konsumen khususnya kaum wanita. Menurut Kertajaya (2002), konsumen di era modern sekarang ini sudah menjadi konsumen yang cerdas dan bijak dalam memilih dan menentukan sebuah pilihan, mempertimbangkan dampak jangka panjang yang ditimbulkan oleh suatu produk kosmetik, memiliki kesadaran akan kesehatan, dan memiliki kesadaran akan lingkungan. Konsumen kini memiliki kesadaran yang lebih baik tentang kecantikan, Kosmetik saat ini dapat diklasifikasikan sebagai barang yang "harus dimiliki".

Terkait dengan penduduk Indonesia dengan mayoritas penduduk memeluk agama Islam yang sudah diwajibkan untuk menggunakan produkproduk yang sesuai dengan syariat Islam. Tren positif dalam permintaan akan produk halal secara global, pada umunya dipengaruhi oleh tingkat pertumbuhan penduduk muslim di dunia dan peningkatan pendapatan pada negaranegara dengan mayoritas memeluk agama Islam. Jika sebelumnya pasar produk-produk halal dianggap tidak memberikan keuntungan dan sangat terbatas. Tetapi faktanya produk-produk halal sekarang menjadi produk yang sangat diminati dan menjadi produk primadona yang banyak sekali di produksi beberapa negara untuk meningkatkan pendapatan negara. Dengan potensi pasar yang di perkirakan $\$ 2,7$ triliun secara global (world halal forum, 2013) dan permintaan yang tidak hanya berasal dari konsumen muslim saja, tetapi banyak negara yang ingin menjadi pusat produk halal seperti negara Malaysia, Thailand, Jepang dan pastinya Indonesia.

Sebagai muslimah yang menerapkan Al-Quran dan Hukum Islam sebagai pedoman di kehidupannya. Hukum memiliki pengertian menurut ulama ushul figh yaitu "Apa yang dikehendaki oleh syari' (pembuat hukum)". Dalam hal ini syari' adalah Allah SWT. Kehendak akan syari' (pembuat hukum) terdapat di Al-Quran dan sudah dijelaskan dalam As-Sunah (Syarifudin Amir, 2011:1). Pastinya akan sangat berhati-hati dalam memilih suatu produk yang akan digunakan termasuk selektif dalam memilih produk dan jasa kecantikan yang sekarang ini sudah semakin banyak dan bervariasi. Banyak produk kecantikan yang di produksi hanya karena ingin mendapatkan profit 
Sitama, et al/Jurnal Ekonomi Syariah Teori dan Terapan Vol. 6 No. 3 Maret 2019: 599-624; FAKTORFAKTOR PENILAIAN KEPUTUSAN KONSUMEN DALAM PEMBELIAN KOSMETIK HALAL (STUDI KASUS MAHASISWI MUSLIMAH FAKULTAS EKONOMI DAN BINIS UNIVERSITAS AIRLANGGA)

sebanyak-banyaknya (profit oriented) dengan menggunakan zat-zat kimia atau bahan-bahan yang berbahaya yang mengandung unsur haram, tanpa memperhitungkan manfaat dan kegunaannya. Dalam Islam konsumsi seorang muslim sudah dibatasi yaitu dengan cara memilih dan membeli pada barang atau suatu produk yang halal dan baik (thayyib).

Konsep Halal sudah dikenal oleh masyarakat Indonesia sendiri yang mayoritas agama nya adalah agama Islam dan telah banyak diterapkan oleh masyarakat Indonesia. Halal dalam Peraturan Pemerintah Republik Indonesia No 69 tahun 1999 pasal (1) yaitu tentang label dan iklan pangan, menyebutkan bahwa yang dimaksud dengan pangan halal adalah pangan yang tidak mengandung unsur atau bahan yang haram atau dilarang untuk konsumsi oleh umat Islam baik yang menyangkut bahan baku pangan, bahan tambahan pangan, bahan bantu, bahan penolong lainnya termasuk bahan pangan yang diolah melalui rekayasa genetika dan iradiasi pangan dan pengelolaannya dilakukan sesuai dengan ketentuan hukum agama Islam (UU No 69 th 1999.pdf). Halal sendiri diperuntukkan bagi sesuatu hal yang bersih dan baik untuk digunakan atau di konsumsi oleh seluruh umat manusia sesuai dengan hukum Islam.

Allah swt berfirman pada surat Al-maidah ayat 3 :

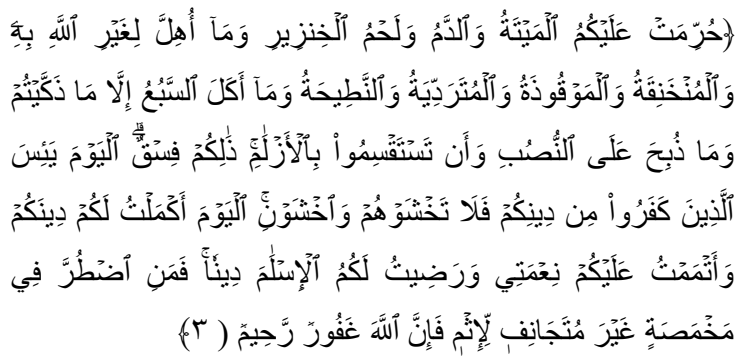
hurrimat 'alaikumul-maitatu wad-damu wa laḥmul-khinzīiri wa mā uhilla ligairillāhi bihī wal-munkhaniqatu wal-mauqụżatu walmutaraddiyatu wan-națịhatu wa mā akalas-sabu'u illā mā żakkaitum, wa mā żubiha 'alan-nușubi wa an tastaqsimụ bilazlām, żālikum fisq, al-yauma ya isallażīna kafarụ min dinikum fa lā takhsyauhum wakhsyaụn, al-yauma akmaltu lakum dīnakum wa atmamtu 'alaikum ni'matī wa raḍîtu lakumul-islāma dīnā, fa maniḍțurra fi makhmașatin gaira mutajānifil lìismin fa innallāha gafụrur rahịm

Artinya: "Diharamkan bagimu (memakan) bangkai, darah, daging babi, (daging hewan) yang disembelih atas nama selain Allah, yang tercekik, yang terpukul, yang jatuh, yang ditanduk, dan diterkam binatang buas, kecuali yang sempat kamu menyembelihnya, dan (diharamkan bagimu) yang disembelih untuk berhala".

Dalam perilaku konsumen Islam yang tidak hanya memikirkan kepuasan saja melainkan dalam bidang konsumsi, Islam sangat tidak menganjurkan pemenuhan keinginan (wants) yang tidak terbatas. Dalam pemenuhan kebutuhan seluruh umat manusia, Islam menyarankan agar manusia melakukan dan bertindak ditengah-tengah (moderity) dan sederhana (simplicity) (Muhammad, 
Sitama, et al/Jurnal Ekonomi Syariah Teori dan Terapan Vol. 6 No. 3 Maret 2019: 599-624; FAKTORFAKTOR PENILAIAN KEPUTUSAN KONSUMEN DALAM PEMBELIAN KOSMETIK HALAL (STUDI KASUS MAHASISWI MUSLIMAH FAKULTAS EKONOMI DAN BINIS UNIVERSITAS AIRLANGGA)

2005:167). Perilaku konsumen dalam memilih produk dan jasa menjadi pendorong persaingan bisnis yang cukup ketat.

Pemenuhan kebutuhan (needs) dan keinginan (wants) yang terpenuhi dapat mempengaruhi perilaku konsumen yaitu bagaimana perilaku individu, perilaku kelompok, dan perilaku organisasi dalam penentuan, pembelian, penggunaan dan bagaimana barang, ide, dan jasa tersebut dapat mengoptimalkan kepuasan dalam mengkonsumsi kebutuhan dan keinginan (Kotler \& Keller, 2008:166). Perilaku konsumen adalah suatu proses pengambilan keputusan yang diambil oleh aktivitas atau kegiatan individu dalam mencari, menentukan, membeli dan juga dalam menggunakan barang dan mengevaluasi barang dan jasa tersebut (Hurriyati, 2010:67).

\section{LANDASAN TEORI}

Menurut Rosyidi (2011:163) definisi dari konsumsi adalah penggunaan atau pemakaian barang atau jasa yang memenuhi kebutuhan manusia secara langsung. Dalam kamus besar Ekonomi konsumsi diartikan sebagai tindakan manusia yang dilakukan secara langsung atau tidak langsung untuk mengurangi dan menghabiskan kegunaan (utility) suatu benda guna untuk pemuasan terakhir dari kebutuhannya (Winarno dan Ismaya, 2017:115).

Konsumsi pada umunya merupakan penggunaan dan pemanfaatan barang dan jasa seperti sandang, pangan, papan, kendaraan, perkakas rumah tangga, media hiburan, dan masih banyak lainnya (Hidayat, 2010:230). Dengan demikian konsumsi tidak hanya semata-mata hanya berkaitan dengan kebutuhan makanan dan minuman saja, namun konsumsi merupakan suatu pemanfaatan guna memenuhi kebutuhan sehari-hari, konsumsi merupakan aspek yang penting dan tidak dapat dipisahkan dengan perilaku manusia dalam pemenuhan kebutuhannya.

Konsumsi memiliki peran yang penting sebagai pilar dalam segala kegiatan rumah tangga, perusahaan dan negara. Tujuan tercapainya konsumsi menurut Islam ialah dimana cara mencapainya telah memenuhi kaidahkaidah pedoman syariah Islamiyyah. Islam sebagai rahmatan lil'alamin agar segala sumber daya terdistribusikan secara adil dan merata. Mengatur bagaimana perilaku konsumsi sesuai dengan hukum atau kaidah Islam yang sudah ditetapkan dalam Al-Quran dan As-Sunnah menjadi salah satu upaya dalam menjamin suatu keadilan distribusi sumber daya.

Konsumsi Islam memiliki tujuan dalam mewujudkan maslahah di dunia dan akhirat. Maslahah duniawi yaitu terpenuhinya segala kebutuhan dasar manusia, yaitu makanan, minuman, pakaian, rumah, kesehatan, dan pendidikan. Maslahah akhirat yaitu 
Sitama, et al/Jurnal Ekonomi Syariah Teori dan Terapan Vol. 6 No. 3 Maret 2019: 599-624; FAKTORFAKTOR PENILAIAN KEPUTUSAN KONSUMEN DALAM PEMBELIAN KOSMETIK HALAL (STUDI KASUS MAHASISWI MUSLIMAH FAKULTAS EKONOMI DAN BINIS UNIVERSITAS AIRLANGGA)

terpenuhinya kewajiban agama seperti shalat dan berangkat haji. Artinya, Manusia makan, minum dan berpakaian tujuannya adalah dapat beribadah kepada Allah SWT.

Dalam ekonomi Islam, konsumsi menjadi sarana yang wajib untuk muslim dan tidak dapat diabaikan dalam merealisasikan tujuan yang sudah menjadi kehendak Allah SWT dalam penciptaan manusia, yaitu pengabdian sepenuhnya hanya kepada Allah SWT seperti pada firman Allah SWT dalam Al-Quran Surat Adz-Dzariyat ayat 56 berikut ini:

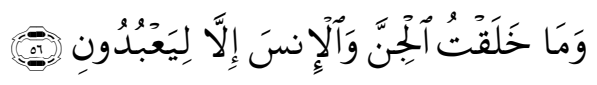

Wa mā khalaqtul-jinna wal-insa illa liya'budụn

Artinya: "Dan aku tidak menciptakan jin dan manusia melainkan supaya mereka mengabdi kepada-Ku".

$$
\text { Menurut Karim }
$$

Konsumsi seorang muslim akan selalu bertindak rasional, sebab itu pengambilan keputusan dari seorang konsumen senantiasa didasarkan pada perbandingan antar berbagai preferensi, peluang, dan manfaat serta mudharat. Konsumen yang bersikap rasional akan menggapai preferensi tertinggi dari segenap peluang dan manfaat yang tersedia dan memilih kombinasi komoditas yang memberikan tingkat utilitas paling besar. Utilitas dalam Islam meliputi mudharat dan maslahat yang ditimbulkan dari mengkonsumsi komoditas tersebut. Untuk mencapai tingkat optimalisasi konsumen, seorang konsumen dibatasi oleh garis anggaran pendapatan.

Teori Perilaku Konsumsi Islam.

Menurut Sarwono perilaku konsumen secara Islam bertujuan untuk tercapainya aspek materil dan aspek spiritual dalam konsumsi, kedua aspek tersebut akan tercapai dengan menyeimbangkan antara nilai guna (total utility) dan nilai guna marginal (marginal utility) dalam konsumsi. Sehingga setiap muslim akan berusaha memaksimumkan nilai guna dari tiap barang yang dikonsumsi, yang akan menjadikan dirinya semakin baik dan semakin optimis dalam menjalani hidup dan kehidupan (Sitepu, 2016:13)

Dalam pandangan Islam perilaku konsumsi harus menghindari perilaku (israf) berlebihan dan (tabzir) boros dalam menggunakan pendapatan untuk memenuhi kebutuhan hidup. Sebagai rambu-rambu dalam konsumsi pangan semesetinya manusia secara umum dan muslim secara khusus senantiasa menjaga unsur ke-halalan dan ke-thayyib an dalam konsumsi sebagai langkah untuk menjaga kesehatan (Bahri, 2014).

Allah SWT berfirman pada surat AlAn'am ayat 141 :

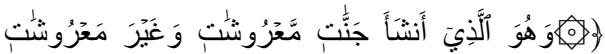

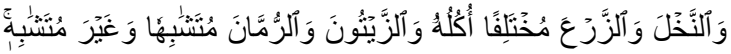

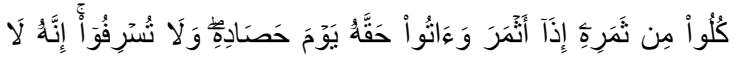

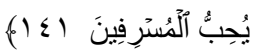
wa huwallażi ansya 'a jannātim ma'rụsyātiw wa gaira ma'rụsyātiw wannakhla waz-zar'a mukhtalifan ukuluhụ waz- 
Sitama, et al/Jurnal Ekonomi Syariah Teori dan Terapan Vol. 6 No. 3 Maret 2019: 599-624; FAKTORFAKTOR PENILAIAN KEPUTUSAN KONSUMEN DALAM PEMBELIAN KOSMETIK HALAL (STUDI KASUS MAHASISWI MUSLIMAH FAKULTAS EKONOMI DAN BINIS UNIVERSITAS AIRLANGGA)

zaitụna war-rummāna mutasyābihaw wa gaira mutasyābih, kulụ min ṡamarihī iżā aṡmara wa ātụ ḥaqqahụ yauma hạạ̄āihī wa lā tusrifụ, innahụ lā yuhibbulmusrifin

Artinya: "Dan Dialah yang menjadikan kebun-kebun yang berjunjung dan yang tidak berjunjung, pohon korma, tanamtanaman yang bermacam-macam buahnya, zaitun dan delima yang serupa (bentuk dan warnanya) dan tidak sama (rasanya). Makanlah dari buahnya (yang bermacam-macam itu) bila dia berbuah, dan tunaikanlah haknya di hari memetik hasilnya (dengan disedekahkan kepada fakir miskin); dan janganlah kamu berlebih-lebihan. Sesungguhnya Allah tidak menyukai orang yang berlebihlebihan.

\section{Harga}

Menurut Sardjono (2009:32) Harga adalah nilai barang dan jasa yang dinyatakan dengan jumlah vang tertentu. Barang dan jasa tersebut memiliki harga, bila barang dan jasa tersebut memiliki nilai dan guna. Selain berguna dan bernilai barang tersebut juga langka atau terbatas. Semakin berguna dan langka akan semakin mahal harga dari barang tersebut, dan sebaliknya jika barang berguna tetapi tidak langka membuat harga barang tersebut tidak relatif mahal.

Menurut Kotler dan Amstrong dalam buku Setyaningrum (2015:128) harga merupakan kesedian konsumen dalam membayarkan sejumlah vang sesuai dengan daya beli, sesuai dengan kualitas, serta membandingkan dengan produk yang lain yang serupa. Secara lebih umum dapat diartikan bahwa harga adalah jumlah dari keseluruhan nilai yang diberikan oleh konsumen untuk mendapatkan keuntungan atas kepemilikan atau penggunaan suatu produk dan jasa. Harga menjadi faktor utama yang dapat mempengaruhi pilihan seorang pembeli.

Dalam pasar terdapat kecenderungan orang memasang harga yang terlalu tinggi dan lainnya memasang harga yang terlalu rendah, namun bagi konsumen hal yang terpenting bukanlah perihal harga yang terlalu tinggi atau terlalu rendah melainkan mendapatkan barang yang sesuai dengan harga yang setara atau adil dalam arti nilai barang tersebut sesuai dengan nilai sebenarnya.

Kepintaran seorang pemasar terletak pada kemampuannya dalam menentukan keseimbangan antara profit (keuntungan) yang diinginkan dan persepsi dari para pembeli terhadap produk yang ditawarkannya (Ibid:129) terdapat dua asumsi yaitu yang pertama seluruh perusahaan akan berperilaku secara rasional dan yang kedua perilaku rasional akan menghasilkan usaha untuk memaksimalkan keuntungan dan meminimalkan kerugian.

\section{Pendapatan}

$$
\text { Menurut Juliana }
$$
pendapatan adalah segala vang atau segala pembayaran yang diterima oleh seseorang atau perusahaan dalam 
Sitama, et al/Jurnal Ekonomi Syariah Teori dan Terapan Vol. 6 No. 3 Maret 2019: 599-624; FAKTORFAKTOR PENILAIAN KEPUTUSAN KONSUMEN DALAM PEMBELIAN KOSMETIK HALAL (STUDI KASUS MAHASISWI MUSLIMAH FAKULTAS EKONOMI DAN BINIS UNIVERSITAS AIRLANGGA)

bentuk gaji atau upah, sewa, bunga, laba, serta tunjangan pengangguran, uang pensiunan dan lain-lain. Sedangkan menurut Muskananfola (2013) pendapatan rumah tangga didefinisikan sebagai pendapatan dari seluruh anggota rumah tangga yang diperoleh dari sumbersumber pendapatan. Hal-hal yang dapat diklasifikasikan sebagai pendapatan rumah tangga antara lain:

1. Pendapatan dalam bentuk upah atau gaji bagi anggota rumah tangga yang bekerja sebagai buruh atau karyawan.

2. Pendapatan lain (laba atau sewa) yang diterima oleh anggota rumah tangga yang mempunyai usaha.

3. Penerimaan dari sumber lainnya yang diterima oleh anggota rumah tangga, seperti tunjangan pemerintah dan bonus (Badan Perencanaan Pembangunan Kota Surabaya, 2004:56).

Menurut Case dan Fair (2007:403) Pada dasarnya pendapatan rumah tangga berasal dari berbagai sumber, hal ini dapat terjadi karena masing-masing anggota rumah tangga memiliki lebih dari satu jenis pekerjaan baik itu sebagai pekerja tetap atau pekerja pengganti. Case menyebutkan bahwa terdapat tiga sumber utama pada pendapatan rumah tangga, yaitu:

1. Upah dan Gaji, upah merupakan balas jasa yang diberikan pada karyawan yang pembayarannya didasarkan oleh hasil kerja dan waktu yang sudah dihabiskan, sedangkan pengertian gaji yaitu merupakan balas jasa bagi karyawan tetap yang diberikan oleh perusahaan yang biasanya ditetapkan secara bulanan (masa kerja yang lebih panjang).

2. Pendapatan dari kekayaan atau hak milik yang tidak hanya berupa uang saja, melainkan dapat berupa lahan perkebunan, emas, bangunan dan masih banyak lagi.

3. Pendapatan dari pembayaran tunjangan pemerintah dan bonus.

\section{Pendapatan Perspektif Islam}

Pendapatan sangat erat kaitannya dengan kepemilikan dan harta dalam Islam. Manusia sebagai khalifah di muka bumi ini hanya diberi hak untuk untuk memanfaatkannya dengan cara yang benar sedangkan pemilik sesungguhnya hanyalah Allah SWT, sebagaimana pada firman Allah dalam surat Al-Baqarah ayat 29 seperti berikut ini:

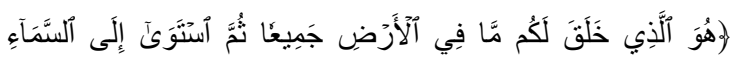

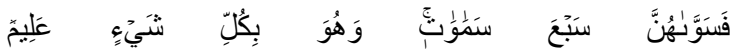
Huwallażī khalaqa lakum mā fil-arḍi jamīan summastawā ilas-samāi fa sawwāhunna sab'a samāwāt, wa huwa bikulli syai in 'alim

Artinya: Dialah Allah, yang menjadikan segala yang ada di bumi untuk kamu dan Dia berkehendak (menciptakan) langit, lalu dijadikan-Nya tujuh langit. Dan Dia Maha Mengetahui segala sesuatu. 
Sitama, et al/Jurnal Ekonomi Syariah Teori dan Terapan Vol. 6 No. 3 Maret 2019: 599-624; FAKTORFAKTOR PENILAIAN KEPUTUSAN KONSUMEN DALAM PEMBELIAN KOSMETIK HALAL (STUDI KASUS MAHASISWI MUSLIMAH FAKULTAS EKONOMI DAN BINIS UNIVERSITAS AIRLANGGA)

\section{Produk Halal}

Pengertian produk secara luas adalah segala sesuatu yang dapat ditawarkan ke pasar untuk mendapatkan perhatian, dibeli, dipergunakan, atau dikonsumsi dan yang dapat memuaskan kebutuhan (Abdullah, 2012:153) Sedangkan menurut Tjiptono (2008:95) secara konseptual produk merupakan pemahaman subyektif dari produsen atas sesuatu yang bisa ditawarkan sebagai usaha untuk mencapai tujuan organisasi melalui pemenuhan kebutuhan dan keinginan konsumen, sesuai dengan kompetensi dan kapasitas organisasi serta daya beli pasar. Menurut Qardhawi (2011:30) Halal merupakan sesuatu yang dengannya terurailah suatu hal yang membahayakan dan Allah SWT memperbolehkan untuk selalu dikerjakan menurut ajaran Islam. Islam datang ketika seluruh umat manusia dalam keadaan yang tidak stabil (zaman jahiliyah), dalam mengkonsumsi suatu makanan atau minuman, mengkonsumsi secara tidak teratur dan suka berlebihlebihan serta juga tidak mengerti dan memahami apa saja hukumnya, pada saat itu umat manusia dalam kebodohan oleh karena itu Allah SWT menurunkan agama Islam untuk mengatur segala kehidupan apa yang ada dibumi, salah satunya yaitu mengatur makanan dan minuman yang halal dan yang dilarang oleh Allah SWT (Qardhawi, 2000:72). Menurut Ghazali (2002:9) suatu perbuatan ataupun benda tidak dapat terlepas dari lima perkara yaitu halal, haram, syubhat, makruh, dan mubah. Allah SWT secara mutlak telah memerintahkan untuk memakan atau mengkonsumsi sesuatu yang baik dan halal. Karena memakan atau mengkonsumsi makanan yang halal dan baik dapat menambah cahaya iman dan membuat terkabul nya banyak doa seperti pada firman Allah SWT pada surat Al-Maidah ayat 88 berikut ini:

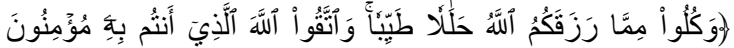

wa kulụ mimmā razaqakumullāhu halālan țayyibaw wattaqullāhallażī antum bihī mu`minụn

Artinya: "Dan makanlah makanan yang halal lagi baik dari apa yang Allah telah rezekikan kepadamu, dan bertakwalah kepada Allah yang kamu beriman kepada-Nya".

Menurut Ahsin (2007:165) Halal merupakan kata yang berasal dari kata dasar yang memiliki arti lepas atau tidak terikat. Sesuatu yang halal berarti sesuatu yang terlepas dari ikatan bahaya duniawi dan ukhrawi. Dan kata thayyib yaitu artinya baik, lezat, tentram, baik dzat nya, baik proses pembuatannya, tidak rusak (kadaluarsa), dan yang paling utama yaitu tidak tercampur oleh benda-benda najis.

Sedangkan menurut keputusan Menteri Agama RI nomor 518 tahun 2001 pada Tanggal 30 November 2001 pasal 1 menjelaskan bahwa pangan halal yaitu pangan yang tidak mengandung bahan 
Sitama, et al/Jurnal Ekonomi Syariah Teori dan Terapan Vol. 6 No. 3 Maret 2019: 599-624; FAKTORFAKTOR PENILAIAN KEPUTUSAN KONSUMEN DALAM PEMBELIAN KOSMETIK HALAL (STUDI KASUS MAHASISWI MUSLIMAH FAKULTAS EKONOMI DAN BINIS UNIVERSITAS AIRLANGGA)

atau unsur suatu yang haram atau yang dilarang untuk digunakan atau dikonsumsi oleh umat Islam dan proses pengelolaannya tidaklah bertentangan dengan hukum dan syariat Islam. Pemeriksaan pangan halal merupakan pemeriksaan tentang keadaan tambahan dan bahan pembantu serta proses produksi, personalia, dan serta peralatan produksi, sistem manajemen halal serta hal-hal lainnya yang berhubungan secara langsung maupun secara tidak langsung dengan kegiatan atau produksi pangan halal.

Jadi berdasarkan pengertian diatas produk halal adalah produk pangan, obat, kosmetik dan produkproduk lainnya yang tidak mengandung bahan atau unsur-unsur barang haram (najis) dalam proses pembuatannya serta dilarang untuk digunakan atau di konsumsi oleh umat Islam baik itu menyangkur dari bahan utama atau bahan baku nya, bahan pembantu, bahan produksi yang diolah melalui proses rekayasa genetika dan iradiasi yang pengolahannya dilakukan sesuai dengan syariat Islam. Produk halal harus lebih memberikan maslahah (manfaat) dibandingkan memberikan dampak mudharat (efek).

1. Proses pembuatan

Proses pembuatan atau proses produksi suatu perusahaan yang sudah meggunakan label halal hendaknya harus tetap menjaga hal-hal sebagai berikut: a. Binatang yang hendak dibersihkan binatang yang sudah mati setelah disembelih.

b. Bahan campuran yang digunakan dalam proses produksi tidak terbuat dari barang-barang atau bahan yang haram dan turunannya.

c. Air yang digunakan untuk membersihkan bahan hendaklah air mutlak atau bersih dan mengalir.

d. Dalam proses produksi tidak tercampur atau berdekatan dengan barang atau bahan yang najis atau haram.

2. Bahan baku utama

Bahan baku adalah bahan utama yang digunakan dalam kegiatan proses produksi, baik berupa bahan baku, bahan setengah jadi maupun bahan jadi. Sedangkan bahan tambahan produk adalah bahan yang tidak digunakan sebagai bahan utama yang ditambahkan dalam proses teknologi produksi.

3. Bahan pembantu

Bahan pembantu atau bahan penolong adalah bahan yang tidak termasuk dalam kategori bahan baku ataupun bahan tambahan yang berfungsi untuk membantu mempercepat atau memperlambat proses produksi termasuk proses rekayasa. Rekayasa genetika adalah suatu proses yang melibatkan pemindahan gen pembawa sifat dari suatu jenis hayati ke jenis hayati lain 
Sitama, et al/Jurnal Ekonomi Syariah Teori dan Terapan Vol. 6 No. 3 Maret 2019: 599-624; FAKTOR-

FAKTOR PENILAIAN KEPUTUSAN KONSUMEN DALAM PEMBELIAN KOSMETIK HALAL (STUDI KASUS MAHASISWI MUSLIMAH FAKULTAS EKONOMI DAN BINIS UNIVERSITAS AIRLANGGA)

yang berbeda atau sama. Sedangkan radiasi merupakan metode penyinaran terhadap produk, baik dengan menggunakan zat radioaktif untuk mencegah terjadinya pembusukan dan kerusakan.

4. Efek

Produk yang halal tidak boleh terlepas dari tujuan syari'at Islam yaitu: mengambil maslahat dan menolak mudharat atau bahaya. Jika menurut kesehatan, suatu jenis produk dapat membahayakan jiwa, maka produk tersebut haram dikonsumsi. Untuk menentukan hukum produk yang tidak terdapat dalam nash maka menggunakan prinsip atau dalil Qawaid, yaitu: Artinya: "Tidak boleh membahayakan diri sendiri dan orang lain" (HR. Ahmad Bin Hanbal).

Adapun dalam pengertian lain produk halal adalah produk yang memenuhi syarat kehalalan sesuai dengan syariat Islam. Syarat-syarat produk halal menurut syari'at Islam antara lain adalah sebagai berikut:

1. Halal zatnya artinya halal dari hukum asalnya.

2. Halal cara memperolehnya artinya cara memperolehnya sesuai dengan syari'at Islam misalkan tidak dengan mencuri.

3. Halal dalam memprosesnya

4. Halal dalam penyimpanannya, tempat penyimpanannya tidak mengandung barang yang diharamkan seperti babi (binatang yang diharamkan oleh Allah).

5. Halal dalam pengangkutannya.

6. Halal dalam penyajiannya artinya dalam penyajian tidak mengandung barang yang diharamkan menurut syari'at Islam (Departemen Agama, 2003).

\section{Label Halal}

Label memiliki hubungan yang erat dengan pemasaran, label merupakan bagian dari produk guna untuk menyampaikan segla informasi tentang apa saja yang terkandung pada produk itu sendiri. Pemberian label (labeling) merupakan elemen dari suatu produk yang sangat penting dan harus mendapatkan perhatian secara seksama dengan tujuan untuk menarik para konsumen dalam membeli sebuah produk atau barang tertentu (Sunyoto, 2013:124).

Label secara umum berisi nama, merek produk, bahan dasar, isi produk dan keterangan legalitas dari suatu produk yang ditawarkan. Sebuah label halal merupakan bagian dari kemasan (packaging) dan dapat menjadi tanda pengenal yang melekat pada sebuah produk. Secara garis besar menurut Sunyoto (2013:125) terdapat tiga macam label yaitu:

1. Brand label, merupakan nama atau sering disebut yang diberikan pada sebuah produk atau suatu nama yang di cantumkan pada kemasan suatu produk. 
Sitama, et al/Jurnal Ekonomi Syariah Teori dan Terapan Vol. 6 No. 3 Maret 2019: 599-624; FAKTORFAKTOR PENILAIAN KEPUTUSAN KONSUMEN DALAM PEMBELIAN KOSMETIK HALAL (STUDI KASUS MAHASISWI MUSLIMAH FAKULTAS EKONOMI DAN BINIS UNIVERSITAS AIRLANGGA)

2. Descriptive label, merupakan label yang memberikan informasi yang bersifat objektif perihal dengan cara penggunaan, pembuatan, konstruksi, perhatian, cara perawatan, dan cara kinerja produk beserta dengan karakteristik lain yang berhubungan dengan produk tersebut.

3. Grade label, merupakan label yang berguna dalam mengidentifikasi penilaian kualitas dari produk tersebut (product's judged quality) dengan satu kata, huruf maupun angka.

Label halal berdasarkan peraturan nomor 69 tahun 1999 tentang label halal dan iklan pangan yang berbentuk gambar, tulisan, kombinasi keduanya atau dapat berbentuk lainnya yang disertakan dalam pangan, dimasukkan ke dalam, atau yang ditempelkan pada bagian kemasan pangan. Menurut pemerintah pasal 10 dan pasal 9 yaitu setiap orang yang memproduksi dan mengemas suatu pangan yang dikemas keseluruh wilayah Indonesia untuk diperjual belikan atau diperdagangkan dan menyatakan bahwa pangan tersebut halal. Bagi umat Islam harus bertanggung jawab atas kebenaran pernyataan tersebut dan memiliki kewajiban untuk mencantumkan keterangan halal atau label halal pada suatu produk atau pangan tertentu (UU NO 69 Tahun 1999.pdf).

\section{Manfaat (Maslahah)}

Dalam ekonomi konvensional, kebutuhan dan keinginan merupakan hal yang tidak dapat dipisahkan. Dimana setiap individu memiliki kebutuhan individu masing-masing. Keinginan seseorang akan sangat berkaitan dengan konsep kepuasan, dan yang menjadi masalah penting jika keinginan tersebut berkembang dan masuk dalam area lampu merah dimana itu adalah area pemenuhan kebutungan dengan cara berlebih-lebihan atau mubazir. Keingininan inilah yang bertentangan dengan prinsip ekonomi Islam. Kemajuan ekonomi dewasa ini menjadikan sebuah produk/jasa menjadi suatu gaya hidup yang membuat manusia tergelincir dalam perilaku israf dan tabdzir. Maka dari itu Islam memisahkan antara kebutuhan (need/hajah) dan keinginan (want/raghbah) manusia (Fauzia dan Riyadi, 2014:162)

Dalam Islam, Konsumsi tidak dapat dipisahkan dari peran keimanan yang sudah menjadi tolak ukur yang penting karena peran keimanan memberikan cara pandang yang cenderung dapat mempengaruhi kualitas dan kuantitas konsumsi baik secara spiritual maupun dalam bentuk kepuasan material. Ketika peran keimanan berada pada tingkat yang baik, maka maka motif dalam berkonsumsi dan berproduksi didominsi oleh tiga motif yaitu maslahah, kewajiban dan kebutuhan. Kebutuhan ditentukan oleh maslahah. Konsep kebutuhan Islam tidak dapat dipisahkan oleh maqashid alsyariah (Muhammad, 2004:152).

Menurut Al-Ghazali kebutuhan merupakan keinginan manusia untuk 
Sitama, et al/Jurnal Ekonomi Syariah Teori dan Terapan Vol. 6 No. 3 Maret 2019: 599-624; FAKTORFAKTOR PENILAIAN KEPUTUSAN KONSUMEN DALAM PEMBELIAN KOSMETIK HALAL (STUDI KASUS MAHASISWI MUSLIMAH FAKULTAS EKONOMI DAN BINIS UNIVERSITAS AIRLANGGA)

mendapatkan sesuatu yang dibutuhkan untuk menjalankan dan mempertahankan kelangsungan hidupnya. Pentingnya niat dalam berkonsumsi sehingga tidak jauh dari makna ibadah, karena konsumsi dilakukan dalam rangka mendekatkan diri kepada Allah SWT (Nasution, 2006:69).

Memenuhi kebutuhan bukan memenuhi keinginan untuk kepuasan saja merupakan tujuan dari aktivitas ekonomi islam dan memiliki tujuan sebagai pencapaian kewajiban dalam agama. Shiddiqi (1979) menyatakan tujuan aktivitas ekonomi yang sempurna menurut Islam antara lain (1) memenuhi kebutuhan hidup seseorang secara sederhana (2) memenuhi kebutuhan keluarga (3) memenuhi kebutuhan jangka panjang (4) menyediakan kebutuhan keluarga yang ditinggalkan (5) memberikan bantuan sosial dan sumbangan sesuai dengan jalan Allah swt (Siddiqi. 2004:15) Pandangan tersebut memiliki tujuan mewujudkan kemaslahatan dalam kehidupan masyarakat.

Perilaku konsumen dalam Islam selalu menekankan pada konsep dasar yaitu cenderung dalam memilih barang atau jasa yang memberikan manfaat (Maslahah) secara maksimal. Hal tersebut merupakan kodrat manusia yang seringkali dikaji oleh para ekonom. Pendekatan tersebut salah satunya dikembangkan oleh Yazid Al Bustami (2015:453) bahwasannya pendekatan akhlak bukan berarti menjauhkan diri dari mengkonsumsi suatu hal-hal yang masih berbau duniawi seperti zuhud. Zuhud memiliki makna yaitu meninggalkan dunia. Pemahaman tersebut tidak mungkin dilakukan oleh siapapun, karena manusia sendiri masih menjalani kehidupan di dunia. Yang benar bahwa karena zuhud seseorang tersebut yang tidak materialistis, membutuhkan materi tapi tidak memiliki sifat tamak dan rakus, merasa cukup puas dengan segala keadaan yang sudah didapatkan hingga saat ini.

Dalam buku Fauzia dan Riyadi (2014:163-164) ada beberapa sifat maslahah yaitu:

1. Maslahah bersifat subjektif yaitu setiap orang menjadi hakim bagi dirinya sendiri dalam menentukan suatu perbuatan yang merupakan suatu maslahah atau bukan untuk dirinya sendiri.

2. Maslahah orang perorang akan konsisten dengan maslahah orang banyak. Konsep ini berbeda dengan konsep pareto optimum dimana keadaan optimal seseorang yang tidak dapat meningkatkan tingkat kepuasan atau kesejahteraannya tanpa menyebabkan penurunan kepuasan atau kesejahteraan orang lain.

Konsep maslahah sangat tepat untuk diterapkan dalam pemenuhan kebutuhan manusia yang terdiri dari kebutuhan dlaruriyat, hajiyat dan tahsiniyat. Masing-masing tujuan yang ingin dicapai oleh Islam yaitu penjagaan terhadap lima hal yaitu (1) Agama (2) 
Sitama, et al/Jurnal Ekonomi Syariah Teori dan Terapan Vol. 6 No. 3 Maret 2019: 599-624; FAKTORFAKTOR PENILAIAN KEPUTUSAN KONSUMEN DALAM PEMBELIAN KOSMETIK HALAL (STUDI KASUS MAHASISWI MUSLIMAH FAKULTAS EKONOMI DAN BINIS UNIVERSITAS AIRLANGGA)

Jiwa (3) Akal (4) Keturunan dan (5) Harta benda. Lima hal tersebut jika tidak tercukupi akan menyebabkan kerusakan bagi kehidupan manusia.

Dalam buku Fauzia dan Riyadi (2014:167) Dalam Islam, tujuan konsumsi bukanlah hanya konsep utilitas atau kepuasan saja melainkan juga kemaslahatan (maslahah). Maslahah dipenuhi berdasarkan pertimbangan rasional, normatif dan positif, maka terdapat kriteria yang objektif tentang suatu barang ekonomi yang memiliki maslahah ataupun tidak.

\section{Skala Prioritas}

Kebutuhan manusia beraneka ragam dan banyak sekali macammacamnya, bahkan tidak hanya beraneka ragam saja tetapi terus bertambah dan tidak ada habisnya terus sejalan dengan perkembangan peradaban dan kemajuan zaman, pengetahuan dan teknologi. Jika kebutuhan satu telah terpenuhi, tentu akan muncul lagi kebutuhan-kebutuhan yang lainnya. Kebutuhan sendiri merupakan keinginan manusia terhadap suatu barang atau jasa yang harus di penuhi. Apabila tidak dipenuhi itu akan berpengaruh terhadap keberlangsungan hidup dan memberikan dampak negatif (Rochmawan, 2008:4).

Dalam menggunakan hasil pendapatan yang terbatas guna memenuhi kebutuhan manusia secara keseluruhan yang tidak terbatas, maka sebaiknya seseorang harus lebih bijak dalam menentukan dan mengutamakan kebutuhannya dibandingkan

keinginannya.

Dalam hal membelanjakan kebutuhan setiap orang melakukannya secara berbeda-beda tergantung kebutuhan dan selera masing-masing. Kebutuhan merupakan segala sesuatu yang harus terpenuhi agar barang tersebut berfungsi secara sempurna sedangkan keinginan merupakan hasrat atau harapan seseorang yang apabila dikonsumsi tidak meningkatkan kesempurnaan dari fungsi suatu barang.

Dalam Islam sudah dijelaskan bahwa keinginan merupakan bagian dari nafsu, nafsu manusia memiliki dua kecenderungan yaitu kecenderungan yang baik dan kecenderungan yang tidak baik. Menurut Al-Ghazali kebutuhan memiliki arti yaitu keinginan manusia untuk mendapatkan segala sesuatu yang dibutuhkannya dalam melangsungkan dan mempertahankan kehidupannya dan menjalankan fungsinya. Secara garis besar pemenuhan akan kebutuhan memberikan tambahan manfaat secara fisik, spiritual, intelektual, maupun secara material, sedangkan dalam pemenuhan keinginan hanya akan menambah kepuasan atau manfaat secara psikis dibandingkan manfaat lainnya. Hal tersebut sangatlah berbeda dalam ekonomi konvensional yang tidak membedakan keinginan (wants) dengan kebutuhan (needs) sehingga dapat memicu terjebaknya konsumen dalam lingkaran konsumerisme. 
Sitama, et al/Jurnal Ekonomi Syariah Teori dan Terapan Vol. 6 No. 3 Maret 2019: 599-624; FAKTORFAKTOR PENILAIAN KEPUTUSAN KONSUMEN DALAM PEMBELIAN KOSMETIK HALAL (STUDI KASUS MAHASISWI MUSLIMAH FAKULTAS EKONOMI DAN BINIS UNIVERSITAS AIRLANGGA)

Menurut Muflih (2006:66-70) Dalam Islam perilaku konsumsi seorang muslim harus diperhatikan dengan jelas dan memperhatikan urutan kepentingan yang di dahulukan (priority) agak tidak terjadi keburukan (mudharat). Urutan prioritas dalam Islam terbagi menjadi tiga yaitu kebutuhan primer (dharuriyat), kebutuhan sekunder (hajiyyat), kebutuhan tersier (tahsiniyat).

1. Kebutuhan primer atau pokok (Dharuriyat) yaitu kebutuhan yang harus terpenuhi untuk menegakkan kemaslahatan agama dan dunia, yang apabila tidak terpenuhi maka akan mengancam keselamatan umat manusia baik di dunia maupun di akhirat. Unsur pokok ini meliputi agama (din), kehidupan (nafs), pendidikan ('aql), keturunan (nasl), dan harta (mal). Semua perintah dan larangan syariat bersumber kepada pemeliharaan lima unsur pokok ini.

2. Kebutuhan sekunder atau kesenangan (Hajjiyat), berfungsi sebagai kebutuhan pelengkap kebutuhan dharuriyat dimana hanya bisa dipenuhi apabila kebutuhan dharuriyat sudah terpenuhi sehingga apabila kebutuhan hajjiyat tidak terpenuhi tidak akan mengancam keselamatan, namun akan mengalami kesulitan. Memaksakan diri keluar dari kebutuhan hajjiyat justru tidak akan memberikan kemaslahatan.

3. Kebutuhan tersier atau kemewahan (Tahsiniyat), merupakan kebutuhan yang apabila tidak terpenuhi tidak akan mengancam keselamatan dan tidak pula menimbulkan kesulitan. Tingkat kebutuhan ini sebagai kebutuhan pelengkap dan hiasan.

Menurut Qardhawy (2005:27) dalam rangka pemenuhan seluruh kebutuhan, setiap manusia harus mempertimbangkan kaidah-kaidah berikut ini sehingga setiap manusia akan merasa puas dengan segala kebutuhan dan keadaan yang didapatkan hingga saat ini, yaitu:

1. Mendahulukan segala kepentingan yang sudah pasti diatas segala kepentingan yang masih diragukan, kepentingan yang baru.

2. Mendahulukan segala kepentingan yang besar diatas kepentingan yang kecil.

3. Mendahulukan kepentingan sosial diatas kepentingan secara individual.

4. Mendahulukan kepentingan kepentingan yang berkesinambungan diatas kepentingan yang bersifat sementara.

5. Mendahulukan segala kepentingan masa depan yang kuat diatas kepentingan kekinian yang lemah.

6. Mendahulukan segala kepentingan yang banyak diatas kepentingan yang kecil.

7. Mendahulukan segala kepentingan yang bersifat inti atau penting (fundamental) diatas kepentingan yang bersifat tidak penting (formalitas).

Berdasarkan kaidah-kaidah didalam rangka pemenuhan segala kebutuhan 
Sitama, et al/Jurnal Ekonomi Syariah Teori dan Terapan Vol. 6 No. 3 Maret 2019: 599-624; FAKTORFAKTOR PENILAIAN KEPUTUSAN KONSUMEN DALAM PEMBELIAN KOSMETIK HALAL (STUDI KASUS MAHASISWI MUSLIMAH FAKULTAS EKONOMI DAN BINIS UNIVERSITAS AIRLANGGA)

manusia maka sudah sesuai dengan prinsip maslahah yang berarti mengutamakan hal yang selalu mendatangkan kebaikan (manfaat). Setiap manusia dimuka bumi ini dalam memenuhi segala kebutuhannya harus memiliki skala prioritas dengan menentukan apa saja kebutuhan yang merupakan kebutuhan yang utama, inti, dan mendesak dan apa saja kebutuhan yang harus ditunda dahulu pemenuhannya supaya dapat mencukupi kebutuhan hidup agar sejahtera dunia dan akhirat sesuai dengan hukum dan tuntunan syariat Islam.

\section{Persepsi Perasaan Boros}

Menurut Walgito (2002:45) persepsi adalah suatu proses yang didahului oleh penginderaan. Definisi penginderaan sendiri berarti suatu proses diterima nya stimulus oleh individu melalui alat penerima yaitu indera, selanjutnya stimulus diteruskan oleh saraf ke otak sebagai susunan saraf, dan proses selanjutnya yaitu persepsi.

Rakhmat (2007:51) berpendapat persepsi adalah pengalaman akan suatu objek, peristiwa-peristiwa, pengalaman, atau hubungan-hubungan yang diperoleh dengan menyimpulkan informasi dan menafsirkan pesan, dan menurut Azhari (2004:106) persepsi dalam arti sempit adalah penglihatan, atau bagaimana cara seseorang memandang/melihat sesuatu hal, sedangkan dalam arti secara luas persepsi adalah pandangan seseorang mengenai bagaimana menilai dan mengartikan sesuatu hal tersebut.

Dari pengertian diatas dapat disimpulkan persepsi merupakan penilaian, tanggapan, atau penglihatan seseorang setelah melakukan rangkaian pengamatan dalam lingkungannya melalui indera, persepsi dilakukan melalui penglihatan, pengamatan dan pendapat.

\section{Prinsip Dasar Persepsi}

Menurut Slameto (2010:103) terdapat lima prinsip dasar tentang persepsi, yaitu:

1. Persepsi itu selektif. Rangsangan yang diterima akan tergantung pada apa yang pernah dipelajari dan apa yang pernah menarik perhatiannya. Ini berarti bahwa ada keterbatasan kemampuan seseorang dalam menerima rangsangan tersebut.

2. Persepsi itu bersifat relatif bukan absolute. Seseorang tidak dapat menyimpulkan secara persis terhadap sesuatu apa yang dilihatnya, tetapi secara relatif seseorang dapat menerka dan menduga terhadap suatu peristiwa berdasarkan kenyatan sebelumnya.

3. Persepsi itu memiliki tatanan. Orang menerima rangsangan tidak dengan cara sembarangan. la akan menerima dalam bentuk hubungan-hubungan atau kelompok. Jika rangsangan tidak datang lengkap maka ia akan melengkapinya sendiri sehingga hubungan itu menjadi jelas. 
Sitama, et al/Jurnal Ekonomi Syariah Teori dan Terapan Vol. 6 No. 3 Maret 2019: 599-624; FAKTORFAKTOR PENILAIAN KEPUTUSAN KONSUMEN DALAM PEMBELIAN KOSMETIK HALAL (STUDI KASUS MAHASISWI MUSLIMAH FAKULTAS EKONOMI DAN BINIS UNIVERSITAS AIRLANGGA)

4. Persepsi seseorang dapat jauh berbeda dengan persepsi orang lain sekalipun situasinya sama. Bahwa perbedaan persepsi dapat ditelusuri apa adanya perbedaan individual, sikap, dan motivasi.

5. Persepsi dipengaruhi oleh kesiapan dan harapan. Harapan dan kesiapan penerima pesan akan menentukan pesan mana yang akan dipilih untuk diterima, selanjutnya bagaimana pesan yang dipilih akan ditata dan diinterpretasikan.

\section{Faktor-Faktor yang mempengaruhi persepsi}

Menurut Sondang (1989:100-105) secara umum terdapat tiga faktor yang dapat mempengaruhi persepsi yaitu:

1. Faktor dari diri orang yang bersangkutan sendiri, yaitu faktor yang timbul apabila seseorang melihat sesuatu dan berusaha memberikan interpretasi tentang apa yang dilihatnya, hal tersebut dipengaruhi oleh karakteristik individual, seperti: sikap, motif, kepentingan, minat, pengalaman, dan harapannya.

2. Faktor dari sasaran persepsi, yaitu faktor yang timbul dari apa yang akan dipersepsi. Sasaran itu bisa berupa orang, benda, atau peristiwa yang sifat-sifat dari sasaran itu biasanya berpengaruh terhadap persersi orang yang melihatnya. Seperti: gerakan, suara, ukuran, tindakan, dan ciri-ciri lain nya dari sasaran persepsi.
3. Faktor dari situasi, yaitu faktor yang muncul sehubungan karena situasi pada waktu mempersepsi. Pada bagian ini persepsi harus dilihat secara kontekstual, yang berarti dalam situasi. Persepsi akan timbul dan perlu mendapatkan perhatian karena situasi merupakan faktor yang ikut berperan dalam penumbuhan persepsi dari seseorang.

\section{Persepsi Perasaan Boros}

Menurut Sari

(2009:22)

menggambarkan perilaku konsumtif atau berlebihan sebagai adanya ketegangan antara keinginan dan kebutuhan manusia, dimana manusia lebih mementingkan faktor keinginan daripada kebutuhan. Sedangkan menurut Dharmesta dan Handoko (2011:107) Perilaku kosumtif merupakan perilaku konsumen yang tidak dapat lagi membedakan antara keinginan dan kebutuhan. Dalam perilaku konsumtif terdapat keinginan dan kebutuhan terdapat keinginan dan kebutuhan yang belum terpenuhi dan terpuaskan. Kebutuhan yang dipenuhi sebenarnya bukan merupakan kebutuhan yang utama melainkan keinginan yang hanya mengikuti arus mode, ingin tahu produk baru, dan membutuhkan pengakuan sosial semata tanpa memperdulikan apakah produk tersebut memang dibutuhkan atau hanya keinginan saja.

Faktor-Faktor yang mempengaruhi
perilaku konsumtif


Sitama, et al/Jurnal Ekonomi Syariah Teori dan Terapan Vol. 6 No. 3 Maret 2019: 599-624; FAKTORFAKTOR PENILAIAN KEPUTUSAN KONSUMEN DALAM PEMBELIAN KOSMETIK HALAL (STUDI KASUS MAHASISWI MUSLIMAH FAKULTAS EKONOMI DAN BINIS UNIVERSITAS AIRLANGGA)

Menurut Engel (1995:46-57)

terdapat dua faktor yang mempengaruhi pembentukan perilaku konsumtif yaitu faktor internal dan faktor eksternal, yang dijabarkan berikut ini:

1. Faktor internal

- Motivasi

- Kepribadian

- Konsep diri

- Pengalaman belajar

- Gaya hidup (Life style)

2. Faktor Eksternal

- Kebudayaan

- Kelas sosial

- Kelompok referensi

- Situasi

- Kelvarga

\section{Indikator Perilaku Konsumtif}

Menurut Sari

(2009:26-27)

pengertian konsep perilaku konsumtif amatlah banyak dan bervariasi, tetapi pada intinya arti utama dari perilaku konsumtif adalah melakukan pembelian barang tanpa adanya pertimbangan rasional dan bukan atas dasar kebutuhan pokok, berikut ini delapan indikator perilaku konsumtif:

1. Membeli produk karena iming-iming hadiah seperti souvenir secara gratis (free)

2. Membeli produk karena kemasan (packaging) menarik, unik atau lucu.

3. Membeli produk demi menjaga penampilan diri dari gengsi.

4. Membeli produk atas pertimbangan harga (bukan atas dasar manfaat atau kegunaannya).
5. Membeli produk hanya sekedar menjaga simbol status.

6. Memakai produk karena ada unsur tertarik dari model atau brand ambassador yang mengiklankan.

7. Munculnya penilaian bahwa membeli produk dengan harga yang tinggi akan menimbulkan bertambahnya rasa percaya diri yang tinggi.

\section{Keputusan Konsumen}

$\begin{array}{rrr}\text { Menurut } & \text { Setiadi } & (2003: 112) \\ \text { Pengambilan } & \text { keputusan } & \text { konsumen }\end{array}$ (consumer decision making) merupakan suatu proses pengintegrasian yang menggabungkan pengetahuan untuk mengevaluasi dua perilaku atau lebih dan menentukan pilihan di salah satu antaranya. Hasil dari proses pengintegrasian ini adalah suatu pilihan (choice) yang disajikan secara kognitif sebagai keinginan berperilaku.

Menurut Kotler dan Keller (2002:166) proses keputusan pembelian dibagi menjadi lima tahapan yang dilakukan oleh konsumen sebelum melakukan keputusan pembelian dan selanjutnya pasca pembelian. Keputusan pembelian dapat terjadi apabila konsumen sudah mendapatkan dampak dari suatu produk atau pelayanan jasa yang sudah dirasakan. Konsep dari keputusan pembelian tidak dapat terlepas dari konsep kepuasan pelanggan. Secara umum manusia bertindak secara rasional dan mempertimbangkan segala jenis informasi yang tersedia dan mempertimbangkan 
Sitama, et al/Jurnal Ekonomi Syariah Teori dan Terapan Vol. 6 No. 3 Maret 2019: 599-624; FAKTORFAKTOR PENILAIAN KEPUTUSAN KONSUMEN DALAM PEMBELIAN KOSMETIK HALAL (STUDI KASUS MAHASISWI MUSLIMAH FAKULTAS EKONOMI DAN BINIS UNIVERSITAS AIRLANGGA)

segala sesuatu yang dapat muncul dari segala tindakan sebelum melakukan sebuah perilaku tertentu.

Berikut lima tahapan yang membagi proses pengambilan keputusan menurut Kotler dan Keller (2012:166) sebagai berikut:

\section{Gambar 1.}

Proses Keputusan Pembelian

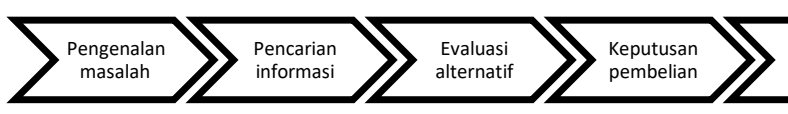

Sumber : Kotler dan Keller (2012:166)

Hipotesis

Penelitian ini ditujukan untuk mengetahui penilaian harga, pendapatan, halal, manfaat, skala prioritas dan persepsi perasaan boros terhadap keputusan konsumen muslimah Fakultas Ekonomi dan Bisnis Universitas Airlangga yang dalam penelitian ini merupakan bentuk perilaku konsumsi secara perspektif Islam. Sesuai dengan rumusan masalah yang sudah dijelaskan pada bab pertama, maka penelitian ini memiliki tujuh hipotesis, yaitu:

1. Harga

HO : Mahasiswi Muslimah FEB Unair tidak mempertimbangkan harga dalam membeli produk kosmetik halal.

H1: Mahasiswi Muslimah FEB Unair mempertimbangkan harga dalam membeli produk kosmetik halal.

2. Pendapatan
HO : Mahasiswi Muslimah FEB Unair tidak mempertimbangkan pendapatan dalam membeli produk kosmetik halal. H1 : Mahasiswi Muslimah FEB Unair mempertimbangkan pendapatan dalam membeli produk kosmetik halal.

3. Halal

HO : Mahasiswi Muslimah FEB Unair tidak mempertimbangkan halal dalam membeli produk kosmetik halal.

H1 : Mahasiswi Muslimah FEB Unair mempertimbangkan halal dalam membeli produk kosmetik halal.

4. Manfaat

$\mathrm{HO}$ : Mahasiswi Muslimah FEB Unair tidak mempertimbangkan manfaat dalam membeli produk kosmetik halal.

H1: Mahasiswi Muslimah FEB Unair mempertimbangkan manfaat dalam membeli produk kosmetik halal.

5. Skala prioritas

HO : Mahasiswi Muslimah FEB Unair tidak mempertimbangkan skala prioritas dalam membeli produk kosmetik halal.

H1: Mahasiswi Muslimah FEB Unair mempertimbangkan skala prioritas dalam membeli produk kosmetik halal.

6. Persepsi perasaan boros

HO : Mahasiswi Muslimah FEB Unair tidak mempertimbangkan boros dalam membeli produk kosmetik halal.

Hl: Mahasiswi Muslimah FEB Unair mempertimbangkan boros dalam membeli produk kosmetik halal.

7. Keputusan Konsumen

HO: Mahasiswi Muslimah FEB Unair merasa tidak yakin mengambil 
Sitama, et al/Jurnal Ekonomi Syariah Teori dan Terapan Vol. 6 No. 3 Maret 2019: 599-624; FAKTORFAKTOR PENILAIAN KEPUTUSAN KONSUMEN DALAM PEMBELIAN KOSMETIK HALAL (STUDI KASUS MAHASISWI MUSLIMAH FAKULTAS EKONOMI DAN BINIS UNIVERSITAS AIRLANGGA)

keputusan dalam membeli produk kosmetik halal.

H1: Mahasiswi Muslimah FEB Unair merasa yakin mengambil keputusan dalam membeli produk kosmetik halal.

III. METODE PENELITIAN

Pendekatan yang digunakan dalam penelitian ini adalah pendekatan kuantitatif. Menurut Sugiyono (2013:23), pendekatan kuantitatif merupakan pendekatan berdasarkan pada filsafat positivisme, digunakan untuk meneliti pada populasi atau sampel tertentu, pengumpulan data menggunakan instrumen penelitian, analisis data bersifat kuantitatif/statistik, bertujuan untuk menguji hipotesis yang telah ditetapkan.

Populasi dalam penelitian ini adalah Mahasiswi Fakultas Ekonomi dan Bisnis Universitas Airlangga Surabaya. Dalam menentukan besarnya sampel, penelitian ini menggunakan cara penentuan sampel menurut Mustafa (2010) yaitu menggunakan Rumus Slovin dengan jumlah populasi sebanyak 3.200 orang Mahasiswi Fakultas Ekonomi dan Bisnis Universitas Airlangga Surabaya dan menggunakan taraf kesalahan sebesar $5 \%$. Berikut adalah perhitungan jumlah sampel untuk penelitian ini.

\section{Rumus 3.1 Slovin}

$$
n=\frac{N}{1+N e^{2}}
$$

\section{Dimana:}

$n=$ Jumlah sampel

$N=$ Jumlah populasi e = Tingkat kesaahan dalam memilih anggota sampel yang ditolerir sebesar $5 \%$

Berdasarkan rumus di atas, maka jumlah sampel yang digunakan dalam penelitian ini adalah sebagai berikut:

$$
\begin{gathered}
n=\frac{3.200}{1+3.200 \times(0,05)^{2}} \\
n=356,556=357 \text { orang }
\end{gathered}
$$

Berdasarkan perhitungan di atas diketahui bahwa jumlah sampel pada penelitian ini adalah sebanyak 357 orang Mahasiswi Fakultas Ekonomi dan Bisnis Universitas Airlangga. Prosedur pelaksanaan accidental sampling yang digunakan dalam penelitian ini adalah dengan mengambil sampel setiap orang yang dijumpai sesuai dengan kriteria penelitian, dalam hal ini adalah Mahasiswi Fakultas Ekonomi dan Bisnis Universitas Airlangga Surabaya Jawa Timur.

\section{Metode Analisis Data}

Dalam penelitian ini, tekhnik analisis yang digunakan adalah analisis uji hipotesis one sample z. Hipotesis merupakan pernyataan mengenai populasi. Hipotesis adalah pernyataan mengenai parameter populasi untuk dibuktikan (Lind, et. al 2014). Data kemudian digunakan untuk memeriksa kelayakan dari suatu pernyataan.

Pengujian hipotesis merupakan langkah yang didasarkan oleh bukti-bukti sampel yang terpakai dalam menentukan hipotesis, apakah hipotesis sudah merupakan suatu pernyataan yang dinilai wajar dan oleh karena itu tidak ditolak, 
Sitama, et al/Jurnal Ekonomi Syariah Teori dan Terapan Vol. 6 No. 3 Maret 2019: 599-624; FAKTORFAKTOR PENILAIAN KEPUTUSAN KONSUMEN DALAM PEMBELIAN KOSMETIK HALAL (STUDI KASUS MAHASISWI MUSLIMAH FAKULTAS EKONOMI DAN BINIS UNIVERSITAS AIRLANGGA)

atau hipotesis merupakan hipotesis yang tidak wajar oleh karena itu harus ditolak.

Hasil dari pengujian statistik baik yang diterima atau ditolak tidak bermaksud dalam membuktikan suatu hal yang bersifat absolut atau benar, melainkan dalam pengujian statistik dapat memberikan bukti yang cukup untuk dapat menerima dan menolak hipotesis tersebut. Alat bantu statistik yang digunakan dalam penelitian ini adalah Minitab 18.

IV.

HASIL DAN PEMBAHASAN

Tabel 2.

Z Test Variabel Harga

\begin{tabular}{|c|r|r|}
\hline \multicolumn{2}{|c|}{$\begin{array}{r}\text { Null hypothesis } \\
\text { Alternative }\end{array}$} & $\mathrm{H}_{0}: \mu \leq 2$ \\
\hline hypothesis & $\mathrm{H}_{1}: \mu>2$ \\
\hline $\begin{array}{c}\text { Sample } \\
\text { (manga }\end{array}$ & 43.59 & 0.000 \\
\hline $\begin{array}{c}\text { Harga } \\
\text { (Terjangkau) }\end{array}$ & 40.80 & 0.000 \\
\hline $\begin{array}{c}\text { Harga } \\
\text { (bersaing) }\end{array}$ & 40.32 & 0.000 \\
\hline
\end{tabular}

Sumber: Diolah Penulis, 2018.

Berdasarkan hasil output tersebut, terlihat bahwa ketiga atribut pertanyaan pada kuisioner variabel harga $\left(X_{1}\right)$ menunjukkan nilai probabilitas (P-Value) 0,00 , sehingga $\mathrm{H}_{0}$ ditolak karena lebih kecil dari tingkat kepercayaan 0.05. Ini menunjukkan bahwa konsumen mempertimbangkan harga sesuai dengan manfaat, harga yang terjangkau, dan harga mampu bersaing dalam membeli produk kosmetik halal.

Tabel 3.

Z Test Variabel Pendapatan

\begin{tabular}{|l|r|l|}
\hline \multicolumn{1}{|c|}{ Sample } & Z-Value & P-Value \\
\hline $\begin{array}{l}\text { Pendapatan tinggi } \\
\text { Konsumsi tinggi }\end{array}$ & 21.97 & 0.000 \\
\hline Null hypothesis & $\mathrm{H}_{0}: \mu \leq 2$ \\
\hline Alternative hypothesis & $\mathrm{H}_{1}: \mu>2$ \\
\hline
\end{tabular}

Sumber: Diolah Penulis, 2018.

Berdasarkan hasil output tersebut, terlihat bahwa pertanyaan pada kuisioner variabel pendapatan $\left(X_{1}\right)$ menunjukkan nilai probabilitas (P-Value) 0,00 , sehingga $\mathrm{H}_{0}$ ditolak karena lebih kecil dari tingkat kepercayaan 0.05. Ini menunjukkan bahwa konsumen mempertimbangkan membeli kosmetik lebih banyak ketika pendapatan tinggi.

Tabel 4.

Z Test Variabel Halal

\begin{tabular}{|c|r|r|}
\hline \multicolumn{2}{|c|}{ Null hypothesis } & $\mathrm{H}_{0}: \mu \leq 2$ \\
\hline \multicolumn{2}{|c|}{ Alternative hypothesis } & $\mathrm{H}_{1}: \mu>2$ \\
\hline Sample & Value & P-Value \\
\hline $\begin{array}{c}\text { Produk halal } \\
\text { (keharusan) }\end{array}$ & 30.56 & 0.000 \\
\hline $\begin{array}{c}\text { Logo halal (pesaing) } \\
\text { Logo halal (aturan } \\
\text { islam) }\end{array}$ & 37.13 & 0.000 \\
\hline $\begin{array}{c}\text { Logo halal (aspek } \\
\text { penting) }\end{array}$ & 31.58 & 0.000 \\
\hline
\end{tabular}

Sumber: Diolah Penulis, 2018.

Berdasarkan hasil output tersebut, terlihat bahwa keempat atribut 
Sitama, et al/Jurnal Ekonomi Syariah Teori dan Terapan Vol. 6 No. 3 Maret 2019: 599-624; FAKTORFAKTOR PENILAIAN KEPUTUSAN KONSUMEN DALAM PEMBELIAN KOSMETIK HALAL (STUDI KASUS MAHASISWI MUSLIMAH FAKULTAS EKONOMI DAN BINIS UNIVERSITAS AIRLANGGA)

pertanyaan pada kuisioner variabel halal $\left(X_{3}\right)$ menunjukkan nilai probabilitas ( $P$ Value) 0,00 , sehingga $\mathrm{H}_{0}$ ditolak karena lebih kecil dari tingkat kepercayaan 0.05. Ini menunjukkan bahwa konsumen mempertimbangkan halal suatu keharusan, logo halal (pesaing), logo halal (aturan Islam), logo halal (aspek penting) dalam membeli produk kosmetik halal.

Tabel 5.

\section{Z Test Variabel Manfaat}

\begin{tabular}{|c|c|c|}
\hline Null hypothesis & \multicolumn{2}{|c|}{$H_{0}: \mu \leq 2$} \\
\hline \multicolumn{3}{|c|}{ Alternative hypothesis $H_{1}: \mu>2$} \\
\hline & Z- & P- \\
\hline Sample & Value & Value \\
\hline Manfaat (wajah) & 26.90 & 0.000 \\
\hline Manfaat (penampilan) & 30.79 & 0.000 \\
\hline Manfaat (tidak alergi) & 25.14 & 0.000 \\
\hline $\begin{array}{c}\text { Manfaat (jangka } \\
\text { panjang) }\end{array}$ & 31.84 & 0.000 \\
\hline
\end{tabular}

Sumber: Diolah Penulis, 2018.

Berdasarkan hasil output tersebut, terlihat bahwa keempat atribut pertanyaan pada kuisioner variabel Manfaat $\left(X_{4}\right)$ menunjukkan nilai probabilitas (P-Value) 0,00 , sehingga $\mathrm{H}_{0}$ ditolak karena lebih kecil dari tingkat kepercayaan 0.05. Ini menunjukkan bahwa konsumen mempertimbangkan manfaat (wajah), manfaat (penampilan), manfaat (tidak alergi), manfaat (Jangka panjang) dalam membeli produk kosmetik halal.

Tabel 6.

Z Test Variabel Skala Prioritas

\begin{tabular}{|l|l|}
\hline Null hypothesis & $\mathrm{H}_{0}: \mu \leq 2$ \\
\hline
\end{tabular}

\begin{tabular}{|lr|r|r|}
\cline { 2 - 4 } \multicolumn{2}{|c|}{ Alternative hypothesis } & $\mathrm{H}_{1}: \mu>2$ \\
\hline \multicolumn{2}{|l|}{ Sample } & $\begin{array}{r}\text { Z- } \\
\text { Value }\end{array}$ & $\begin{array}{r}\text { P- } \\
\text { Value }\end{array}$ \\
\hline \multicolumn{2}{|l|}{ skala prioritas (pangan) } & 44.80 & 0.000 \\
\hline $\begin{array}{l}\text { skala prioritas } \\
\text { (pendidikan) }\end{array}$ & 45.08 & 0.000 \\
\hline $\begin{array}{l}\text { skala prioritas } \\
\text { tinggal }\end{array}$ & 44.99 & 0.000 \\
\hline $\begin{array}{l}\text { skala prioritas } \\
\text { (kesehatan) }\end{array}$ & 45.08 & 0.000 \\
\hline
\end{tabular}

Sumber: Diolah Penulis, 2018.

Berdasarkan hasil output tersebut, terlihat bahwa keempat atribut pertanyaan pada kuisioner variabel Skala Prioritas $\left(\mathrm{X}_{5}\right)$ menunjukkan nilai probabilitas (P-Value) 0,00 , sehingga $\mathrm{H}_{0}$ ditolak karena lebih kecil dari tingkat kepercayaan 0.05. Ini menunjukkan bahwa konsumen mempertimbangkan skala prioritas (pangan), skala prioritas (pendidikan), skala prioritas (tempat tinggal), skala prioritas (kesehatan) dalam membeli produk kosmetik halal.

Tabel 7.

Z Test Variabel Persepsi Perasaan Boros

\begin{tabular}{|c|r|r|}
\hline \multicolumn{2}{|c|}{ Null hypothesis } & $H_{0}: \mu \leq 2$ \\
\hline \multirow{2}{|c|}{$\begin{array}{c}\text { Alternative hypothesis } \\
\text { Sample }\end{array}$} & $\begin{array}{r}\mathrm{H}_{1}: \mu>2 \\
\text { Value }\end{array}$ & $\begin{array}{r}\text { P- } \\
\text { Value }\end{array}$ \\
\hline $\begin{array}{c}\text { Persepsi (packaging unik } \\
\text { lucu) }\end{array}$ & 10.94 & 0.000 \\
\hline Persepsi (satu paket) & 4.02 & 0.000 \\
\hline Persepsi (ganti baru) & 8.75 & 0.000 \\
\hline Persepsi (sedang trend) & 7.48 & 0.000 \\
\hline
\end{tabular}

Sumber: Diolah Penulis, 2018. 
Sitama, et al/Jurnal Ekonomi Syariah Teori dan Terapan Vol. 6 No. 3 Maret 2019: 599-624; FAKTORFAKTOR PENILAIAN KEPUTUSAN KONSUMEN DALAM PEMBELIAN KOSMETIK HALAL (STUDI KASUS MAHASISWI MUSLIMAH FAKULTAS EKONOMI DAN BINIS UNIVERSITAS AIRLANGGA)

Berdasarkan hasil output tersebut,

terlihat bahwa keempat atribut pertanyaan pada kuisioner variabel Persepsi Perasaan Boros $\left(\mathrm{X}_{6}\right)$ menunjukkan nilai probabilitas (P-Value) 0,00 , sehingga Ho ditolak karena lebih kecil dari tingkat kepercayaan 0.05. Ini menunjukkan bahwa konsumen mempertimbangkan persepsi (packaging unik dan lucu), persepsi (satu paket), persepsi (ganti baru), persepsi (sedang trend) dalam membeli produk kosmetik halal.

Tabel 8.

\section{Z Test Variabel Keputusan Konsumen}

\begin{tabular}{|l|r|r|}
\hline \multicolumn{2}{|l|}{ Null hypothesis } & $\mathrm{H}_{0}: \mu \leq 2$ \\
\hline \multicolumn{2}{|l|}{ Alternative hypothesis } & $\mathrm{H}_{1}: \mu>2$ \\
\hline Sample & Z-Value & P-Value \\
\hline Keputusan tepat & 42.99 & 0.000 \\
\hline
\end{tabular}

Sumber: Diolah Penulis, 2018.

Berdasarkan hasil output tersebut, terlihat bahwa pertanyaan pada kuisioner variabel Keputusan Konsumen $\left(Y_{1}\right)$ menunjukkan nilai probabilitas (P-Value) 0,00 , sehingga $\mathrm{H}_{0}$ ditolak karena lebih kecil dari tingkat kepercayaan 0.05. Ini menunjukkan bahwa Konsumen merasa yakin dalam mengambil keputusan saat membeli produk kosmetik halaL.

\section{v. SIMPULAN}

Simpulan pada penelitian yang berjudul "Penilaian Harga, Pendapatan, Label Halal, Manfaat, Skala Prioritas, Persepsi Perasaan Boros dan Keputusan Konsumen Muslimah Dalam Pembelian Kosmetik Halal; Studi Kasus Mahasiswi
Fakultas Ekonomi dan Bisnis Universitas Airlangga Surabaya, Jawa Timur" adalah sebagai berikut:

1. Penilaian Harga tingkat signifikasi $5 \%$ secara parsial menunjukkan bahwa konsumen mempertimbangkan harga sesuai dengan manfaat, harga yang terjangkau, dan harga mampu bersaing dalam membeli produk kosmetik halal.

2. Penilaian pendapatan tingkat signifikasi 5\% secara parsial menunjukkan bahwa konsumen mempertimbangkan dalam membeli produk kosmetik lebih banyak ketika pendapatan lebih tinggi.

3. Penilaian halal tingkat signifikasi $5 \%$ secara parsial menunjukkan bahwa konsumen mempertimbangkan halal suatu keharusan, logo halal (pesaing), logo halal (aturan Islam), logo halal (aspek penting) dalam membeli produk kosmetik halal.

4. Penilaian manfaat tingkat signifikasi $5 \%$ secara parsial menunjukkan bahwa konsumen mempertimbangkan manfaat (wajah), manfaat (penampilan), manfaat (tidak alergi), manfaat (jangka panjang) dalam membeli produk kosmetik halal.

5. Penilaian skala prioritas signifikasi $5 \%$ secara parsial menunjukkan bahwa konsumen mempertimbangkan skala prioritas (pangan), skala prioritas (kesehatan), skala prioritas (pendidikan), skala prioritas (tempat tinggal) dalam membeli produk kosmetik halal. 
Sitama, et al/Jurnal Ekonomi Syariah Teori dan Terapan Vol. 6 No. 3 Maret 2019: 599-624; FAKTORFAKTOR PENILAIAN KEPUTUSAN KONSUMEN DALAM PEMBELIAN KOSMETIK HALAL (STUDI KASUS MAHASISWI MUSLIMAH FAKULTAS EKONOMI DAN BINIS UNIVERSITAS AIRLANGGA)

6. Penilaian persepsi perasaan boros signifikasi $5 \%$ secara parsial menunjukkan bahwa konsumen mempertimbangkan persepsi (packaging unik dan lucu), persepsi (ganti baru), persepsi (sedang trend) dalam membeli produk kosmetik halal.

7. Penilaian keputusan konsumen signifikasi $5 \%$ secara parsial menunjukkan bahwa konsumen merasa yakin dalam mengambil keputusan saat membeli produk kosmetik halal.

\section{DAFTAR PUSTAKA}

Abdullah, Thamrin dan Francis Tantri. 2012. Manajemen Pemasaran. Jakarta: PT. Raja Grafindo Persada.

Alhafidz, Ahsin W. 2007. Fikih Kesehatan. Jakarta: Amzah

Engel, James F, et al. 1994. Perilaku Konsumen Jilid 1 hal 69. Jakarta:Binarupa Aksar

Juliana Ibnu Mubarok. 2012. Kamus Istilah Ekonomi. Bandung: Yrama Widya

Karim, Adi warman. 2012. Ekonomi Mikro Islam. Jakarta: Rajawali Press

(https://kemenag.go.id/berita/read/30290 $\underline{0}$, diakses 12 september 2018

Kotler, philip dan kevin lane keller. 2003. Manajemen Pemasaran Edisi 13 terjemahan Bob Sabran. Jakarta: Erlangga

Muflih, Muhammad. 2006. Perilaku Konsumen dalam perspektif IImu Ekonomi Islam. Jakarta: PT.Raja Grafindo.
Muhammad. 2004. Ekonomi Mikro dalam Perspektif Islam. Yogyakarta : BPFE Yogyakarta

Nasution, Mustafa Edwin et al. 2006. Pengenalan Eksklusif Ekonomi Islam. Jakarta: Kencana Prenadamedia Group

Qardhawi, Yusuf. 2000. Halal dan Haram dilengkap Takhrij Hadits.Jakarta : Robbani Press

Rakhmat, Jalaludin. 2007. Psikologi komunikasi. Bandung PT Remaja Rosdakarya.

Rosyidi, Suherman. 2014. Pengantar Teori Ekonomi Pendekatan kepada Teori Ekonomi Mikro \& Makro. Jakarta: Raja Grafindo Persada

Sari, Tiurma Yustisi. 2009. Hubungan antara Perilaku Konsumtif dengan Body Image pada Remaja Putri. Skripsi S1. Sumatera Utara: Universitas Sumatera Utara.

Setiadi, Nugroho J. 2013. Perilaku Konsumen. Jakarta: Kencana Prenada Media Group.

Setyaningrum, Ari., et al. 2015. PrinsipPrinsip Pemasaran Plus Tren Terkini. Yogyakarta: Andi Offset

Sitepu, Novi Indriyani. 2016. Jurnal Perspektif Ekonomi Darussalam. Volume 2 No 1 hal 13. ISSN 25026976

Slameto. 2010. Belajar \& Faktor-Faktor yang Mempengaruhi. Jakarta: Rineka Cipta 
Sitama, et al/Jurnal Ekonomi Syariah Teori dan Terapan Vol. 6 No. 3 Maret 2019: 599-624; FAKTOR-

FAKTOR PENILAIAN KEPUTUSAN KONSUMEN DALAM PEMBELIAN KOSMETIK HALAL (STUDI KASUS MAHASISWI MUSLIMAH FAKULTAS EKONOMI DAN BINIS UNIVERSITAS AIRLANGGA)

Sondang, P Siagaan. 1989. Teori Motivasi dan Aplikasinya. Jakarta :Rineka Cipta

Sudremi, Yuliana. 2007. Pengetahuan Sosial Ekononomi Kelas X. Jakarta: Bumi Aksara

Sunyoto, Danang. 2013. Dasar-Dasar

$$
\text { Manajemen } \quad \text { Pemasaran. }
$$

Syarifuddin, Amir. 2011.Ushul Fiqh Jilid 2. Jakarta : Kencana

Tjiptono, Fandy. 2006. Pemasaran Jasa hal 2. Malang : Bayumedia Publishing Todaro. 2002. Ekonomi Dalam Pandangan Modern. Jakarta : Bina Aksara

World Halal Forum, 2013. (http://www.worldhalalforum.org/ whf_intro.html, diakses 12 September 2018). 